\title{
BIOETYKA KONFUCJAŃSKA JAKO ODPOWIEDŹ NA WYZWANIA WSPÓŁCZESNEJ BIOMEDYCYNY
}

Celem niniejszego opracowania jest przedstawienie podstawowych założeń etyki konfucjańskiej w kontekście współczesnej refleksji bioetycznej, poruszającej różne aspekty narodzin, życia i śmierci człowieka. Przedmiotowa analiza ma charakter przeglądowy, pozwala przybliżyć dorobek tradycyjnej myśli chińskiej, wywodzącej się z nauk Konfucjusza i rozwijanej przez jego kontynuatorów. Opisano kształtowanie się globalnego rynku nowych technologii w warunkach wysoko konkurencyjnych gospodarek, spośród których czołowe miejsce zajmuja Chiny mogące rywalizować z zachodnimi firmami biotechnologicznymi. Wskazano na możliwość aplikacji doktryny konfucjańskiej, opartej na cnotach humanitarności, prawości, właściwego zachowania, mądrości i wierności, na gruncie bioetyki i bioprawa.

\section{Kształtowanie się refleksji bioetycznej we współczesnych Chinach}

Dynamiczny rozwój biologii, medycyny i technologii stał się przyczynkiem do podjęcia pogłębionej refleksji etycznej dotyczącej ingerencji w naturalne procesy życia, co doprowadziło do wyłonienia się w drugiej połowie XX wieku nowej dziedziny bioetyki. Dyscyplina ta ma łączyć wiedzę naukową z systemem wartości etycznych, stanowiąc swoisty pomost między współczesnymi osiagnięciami nauk przyrodniczych a dorobkiem myśli humanistycznej, ma skłaniać do zastanowienia się nad problemem wzajemnej relacji nauki i etyki. Przegląd stanowisk różnych autorów zajmujących się zagadnieniem bioetyki pozwala zauważyć, że obecnie „bioetyczny” wektor jest skierowany od bioetyki globalnej ku bioetyce lokalnej (np. afrykańska, buddyjska, islamska, japońska, konfucjańska), a tym samym następuje stopniowe przejście od myślenia uniwersalnego na rzecz optyki regionalnej.

Dokonanie wielu odkryć na polu nauk przyrodniczych w ciagu ostatnich lat dało asumpt do przygotowania innowacyjnych metod diagnostycznych i terapeutycznych, niosąc osobom chorym nadzieję na poprawę stanu zdrowia lub powrót do pełnej sprawności. W różnych regionach świata podejmowane są zaawansowane prace mające na celu zorganizowanie sektora wysokich technologii (bi-tech), na szczególną uwagę zasługują tutaj region wschodnioazjatycki (Chiny, Japonia, Korea 
Południowa, Malezja, Singapur), północnoamerykański (Kanada, Meksyk, USA) i zachodnioeuropejski (Francja, Holandia, Niemcy). Symptomatycznym zjawiskiem jest zajmowanie przez Chiny pierwszej lokaty w rankingu dotyczącym eksportu produktów zaawansowanych technologii, co podkreśla ważną rolę Państwa Środka na globalnym rynku nowych rozwiązań technicznych ${ }^{1}$. Rząd chiński dąży do rozwijania krajowej bazy technologicznej i stopniowego ograniczania zależności od państw zachodnich w tej sferze, podejmując działania ukierunkowane na wzrost jakości lokalnych firm technologicznych ${ }^{2}$. Wyrazem opisywanej dynamiki jest ekspansja giganta biotechnologicznego BGI (Beijing Genomics Institute), jednej z największych na świecie firm zajmujących się sekwencjonowaniem DNA, posiadającej swoje laboratoria w Chinach, Europie i Ameryce Północnej'.

Początki badań biomedycznych i bioetyki w ojczyźnie Konfucjusza należy łączyć z powstaniem w 1986 r. strategii w sprawie przyspieszenia rozwoju zaawansowanych technologii (tzw. program 863), która zyskała aprobatę chińskiego przywódcy Denga Xiaopinga ${ }^{4}$. Z pewnością rząd ChRL doskonale wyczuł trendy związane z badaniami biomedycznymi, gdyż - jak wiadomo - właśnie w połowie lat 80 . rozpoczęto prace w ramach międzynarodowego projektu poznania ludzkiego genomu (HGP), dzięki czemu w 2003 r. zakończono w ponad 99\% sekwencjonowanie genomu człowieka. Warto dodać, że w tym zakrojonym na szeroką skale przedsięwzięciu swój udział miały również Chiny, jako że BGI był odpowiedzialny za odczytanie sekwencji 1\% genomu człowieka. W następnych latach naukowcy z Chin dokonali m.in. przeszczepu tkanki psiego pęcherza do organizmu myszy, odczytali sekwencje genomów ryżu, pandy wielkiej, ogórka, człowieka z epoki starożytnej i ponad tysiąca bakterii jelitowych, podobno nawet sklonowali ludzkie embriony, używając komórek jajowych królika i ludzkiego DNA ${ }^{5}$. W podanym okresie stworzono również China Kadoorie Biobank, stanowiący bazę do prospektywnych badań kohortowych z wykorzystaniem ludzkiego materiału genetycznego, liczacy obecnie próbki pochodzące od około 0,5 mln uczestników. W listopadzie 2018 r. jeden z chińskich naukowców poinformował, że dzięki zastosowaniu me-

1 W 2016 r. łączny eksport produktów hi-tech z Chin wynosił 496,007 mld USD - dla porównania eksport bi-tech z Niemiec to 189,646 mld USD, zaś z USA to 153,189 mld USD; http:// wdi.worldbank.org/table/5.13 (dostęp: 1.10.2018). Zob. stanowisko polemiczne: Y. Xing, China's High-Tech Exports: The Myth and Reality, „Asian Economic Papers” 2014, vol. 13, no. 1, s. 109-123.

2 Postep technologiczny priorytetem w rozwoju chinskiej gospodarki, oprac. WPHI Szanghaj, http:// www.gochina.gov.pl/files/?id_plik=414 (dostęp: 1.10.2018).

3 Por. D. Cyranoski, China's genomics giant to make stock-market debut, „Nature” 2017, vol. 546, s. 461; http://www.nature.com/news/china-s-genomics-giant-to-make-stock-market-debut-1.22171 (dostęp: 1.10.2018).

4 The Editors of The New Atlantis, Chinese Bioethics?, „The New Atlantis”, Spring 2003, no. 1, s. 138-140; http://www.thenewatlantis.com/publications/chinese-bioethics (dostęp: 1.10.2018).

5 D. Cyranoski, China's genomics giant..., s. 461; V. Barry, Cengage Advantage Books: Bioethics in a Cultural Context: Philosophy, Religion, History, Politics, Boston-Wadsworth 2012, s. 241. 
tody CRISPR-Cas9 urodziły się pierwsze na świecie dzieci o zmodyfikowanym materiale genetycznym ${ }^{6}$.

To krótkie spojrzenie na dotychczasowe osiagnięcia Chin w zakresie nowoczesnej biotechnologii, niejako z lotu ptaka, ukazuje wysoką konkurencyjność krajowego rynku w skali globalnej. Znajduje się on niewątpliwie w światowej czołówce branży nowych technologii, odważnie rywalizując z firmami z USA oraz Unii Europejskiej. Należy jednak uprzytomnić sobie, że utylitarne czy pożądane cele działalności ekonomicznej powinny harmonizować z powszechnie uznawanymi wartościami: godności człowieka, zdrowia, wolności, autonomii, integralności cielesnej, prywatności. Bioetyka spełnia w pewnym sensie funkcję delimitacyjną na polu badań biomedycznych, wskazując właściwe ramy do przedsiębrania ryzykownych działań naukowo-badawczych, które wiążą się z koniecznością proporcjonalnego zbilansowania możliwych korzyści i strat. Jak słusznie zauważył Jean Bernard: „,pogranicza oddzielające bioetykę od sąsiednich dziedzin [tj. nauki, medycyny, filozofii, teologii, polityki, ekonomii czy prawa - K.G.] są różnorodne, złożone, czasem ruchome" ". Choć wydaje się, że określone aspekty bioetyki powinny być rozumiane tak samo pod każdą szerokościa geograficzna, to nie jest to do końca słuszna teza, albowiem czynniki lokalne mogą mieć znaczący wpływ na wyrażane poglądy etyczne (np. symbolika krwi w różnych kulturach, występowanie specyficznych chorób w obrębie danej populacji, miejscowa relacja popytu i podaży $)^{8}$.

Analiza chińskiej bioetyki, zwłaszcza dla Europejczyka, nie jest łatwa, chociażby ze względu na pokusę etnocentryzmu, kulturowej projekcji czy logocentryzmu. Kontestowanie niektórych etycznych problemów przez naukowców z Chin nie oznacza per se relatywizacji świata wartości, lecz raczej stanowi odzwierciedlenie wartości właściwych dla lokalnego kręgu kulturowego, zrozumiałych przez pryzmat miejscowej filozofii, religii oraz tradycji. Generalnie chińska bioetyka obficie czerpie nie tylko z myśli konfucjańskiej, ale także taoistycznej i buddyjskiej. Nauki Konfucjusza oddziałują od przeszło 2 tysięcy lat na sposób myślenia mieszkańców Państwa Środka, w tym na kwestie narodzin, życia i śmierci człowieka. Czy jednak tradycja konfucjańska daje możliwości rozstrzygania współczesnych dylematów bioetycznych? Aby można odpowiedzieć na to pytanie, należy uczynić punktem wyjścia holistyczną perspektywę ludzkiego zdrowia, w której sfera duchowa, umysłowa i cielesna znajdują się we wzajemnej interakcji, stanowiąc nierozerwalna, harmonijną całość. Ludzkie ciało w swej istocie jest powiązane z całym porządkiem

6 M. Kossobudzka, Chiński eksperyment: pierwsze dzieci GMO? Naukowy śniat zaszokowany; http:// wyborcza.pl/7,75400,24213846,pierwsze-dzieci-gmo.html (dostęp: 9.12.2018).

Cyt. za: J. Bernard, Od biologii do etyki, tłum. J.A. Żelechowska, Warszawa 1994, s. 146.

8 Ibidem, s. 165. Pogląd, zgodnie z którym uwarunkowania geograficzne, w tym głównie klimat, decydują o kulturze, ustroju politycznym i systemie prawnym określonych narodów, został wyrażony przez Ch. Monteskiusza w jego najbardziej znanym dziele $O$ duchu praw (De l'espirit des lois, 1748). 
kosmosu, uczestniczy przez całe życie w naturalnym procesie przemian. Zgodnie z chińską tradycją ciało człowieka składa się z pięciu podstawowych elementów: wody, ognia, ziemi, metalu i drzewa, i to właśnie zachowanie właściwych proporcji pomiędzy nimi ma decydować o naszej kondycji fizycznej lub moralnej’.

\section{Problemy narodzin, życia i śmierci w kontekście myśli konfucjańskiej}

Godny uwagi jest pogląd Konfucjusza, zgodnie z którym życie biologiczne nie stanowi wartości najwyższej. W tym miejscu wypada odwołać się do dwóch kardynalnych cnót konfucjańskich, tj. humanitarności $(r e n)$ i prawości (yz), będących w przekonaniu myśliciela nadrzędnym dobrem, cenniejszym niż konieczność zachowania jednostkowego życia. Jak sam to podkreśla: „Człowiek życzliwy, pełen dobrych chęci / To za życzliwość swe życie poświęci. / I nie pozwoli, aby jego życie / Mogło zaszkodzić życzliwości skrycie"10. Przestrzeganie ren oraz yi jest nakazem moralnym skierowanym do człowieka szlachetnego (君子 - jun₹l), dążącego do humanitarnego, mądrego i uczciwego postępowania. Zgodnie z tym stanowiskiem życie nie jest wartością autoteliczna, a jego sens zależy od wypełniania ren oraz yi jako podstawy wszelkich ludzkich działań. Z tego punktu widzenia nie chodzi już o to, by zachować i chronić życie za wszelką cenę czy też o godne umieranie, gdyż bezwarunkowym obowiązkiem człowieka staje się przede wszystkim utrzymywanie dwóch wymienionych cnót $t^{11}$.

Etyka konfucjańska opiera się zatem na założeniu, że tylko dzięki kultywowaniu cnoty człowiek może osiagać wewnętrzną harmonię i rozwijać dobre relacje z innymi ludźmi. Zdaniem Konfucjusza podejmowanie wysiłku na wspomnianej drodze ma przejawiać się poprzez zachowywanie pięciu podstawowych cnót: humanitarności (仁 - ren), prawości (義 - yl), właściwego zachowania (禮 - li), mądrości (智 - zhi) oraz wierności (信 - xin).

Termin ren oznacza wewnętrzną zdolność każdego człowieka do czynienia dobra, odróżniająca go od zwierząt; można go przetłumaczyć jako humanitarność, życzliwość, altruizm lub dobro. Starożytny myśliciel próbuje opisać ren za pomoca jego atrybutów, do których zalicza wytrwałość i umiejętność znoszenia trudności,

9 Por. R. Fan, Introduction: Towards a Confucian Bioethics [w:] Confucian Bioethics, ed. R. Fan, vol. 61, New York-Boston-Dordrecht 2002, s. 4-8; E.Y. Zhang, The Neo-Confucian Concept of Body and Its Ethical Sensibility [w:] Confucian Bioethics..., s. 46. Nietrudno dostrzec analogię między chińską koncepcją pięciu elementów a grecką koncepcją czterech żywiołów (ogień, powietrze, woda, ziemia).

${ }^{10}$ Cyt. za: Rozważania (Dialogi konfucjańskie), tłum. J. Zawadzki, Seattle 2012, s. 187.

11 P.-Ch. Lo, Confucian Views on Suicide and Their Implications for Euthanasia [w:] Confucian Bioethics..., s. 70-72. 
brak pretensji i żalu do innych, empatię, okazywanie miłości ludziom, zdobywanie i pogłębianie wiedzy. Z kolei pojęcie yi łączy się z prawościa, sprawiedliwością, uczciwością, dzięki czemu określona jednostka zachowuje się, jak należy, czyli podejmuje właściwe działanie w odpowiedniej sytuacji. Prawość jest jedną z najważniejszych cech wymaganych od osób sprawujących władzę, opiekę czy nadzór, np. nauczyciela, sędziego i lekarza. Trzeci element podanej kompozycji, czyli li, odnosi się do właściwego zachowania, rozumianego jako konieczność stosowania etykiety, kurtuazji, rytuału, a więc zespołu zwyczajów i konwencji społecznych ukształtowanych na drodze tradycji, wzmacniających więzi międzyludzkie ${ }^{12}$. Zhi to zarówno wiedza, jak i wewnętrzna zdolność do odróżniania dobra i zła, natomiast xin to uczciwość, dotrzymywanie obietnic, wierność danemu słowu ${ }^{13}$.

W centrum myśli konfucjańskiej leży zasada humanitarności, u której podstaw jest wiara w zdolność wszystkich ludzi do podnoszenia na wyższy poziom swoich indywidualnych oraz wspólnotowych warunków życia, w szczególności dzięki samodoskonaleniu i samorozwojowi. Jeszcze raz należy przypomnieć charakterystyczne dla tej szkoły stanowisko, zgodnie z którym w razie konieczności powinno się poświęcić życie w celu utrzymania rudymentarnych wartości ren oraz $y i^{14}$. Według chińskiego myśliciela większą rolę we wzajemnym współżyciu jednostek odgrywają normy moralne i obyczajowe, mniejsza zaś - prawo stanowione. Warto zastanowić się, w jaki sposób konfucjanizm zapatruje się na drażliwe kwestie społeczne, budzące duże kontrowersje, jak np. eutanazja, samobójstwo, aborcja, kara śmierci. Zrezygnowanie z wypełniania w życiu podstawowych cnót prowadzi w kierunku etycznej degradacji człowieka, co przynosi skutki gorsze niź śmierć.

Biorąc to pod uwagę, w myśl konfucjanizmu w pewnych okolicznościach odebranie życia może być etycznie usprawiedliwione, gdy służy jakimś nadrzędnym wartościom. Odmiennie niż w kulturze zachodniej, w kręgu chińskiej kultury przypisuje się prymat doktrynie świętości cnót moralnych, nie zaś doktrynie świętości ludzkiego życia. I tak bezwarunkowemu obowiązkowi kontynuowania życia przeciwstawia się bezwarunkowy nakaz utrzymania wewnętrznego porządku moralnego. Konieczność ochrony godności lub honoru, jak chociażby w sytuacji upokorzenia przez wroga (np. śmierć cesarza Zhao Binga w 1279 r. podczas najazdu mongolskiego) lub w celu uniknięcia hańbiącego zarzutu przed sądem (np. przypadek japońskiego księcia Konoe w 1945 r.), zyskuje - w podanej perspektywie etycznej - akceptację.

Powyższa konstatacja pokazuje, że w przeciwieństwie do dominujących na Zachodzie poglądów tradycyjna etyka chińska dopuszczała możliwość popełnienia samobójstwa w imię jakichś wyższych wartości. W nauce klasycznej szkoły konfucjańskiej

12 Por. The Analects of Confucius, tłum. A.Ch. Muller; http://www.acmuller.net/con-dao/analects.html (dostęp: 5.10.2018).

13 Y. Cong, Bioethics in China [w:] Annals of Bioethics: Regional Perspectives in Bioethics, eds. J.F. Peppin, M.J. Cherry, New York 2017, s. 242-243.

14 H. Epps, The Universal Golden Rule, Morrisville, North Carolina 2012, s. 62. 
ochrona ludzkiego życia biologicznego jest dobra, ale nie jest najwyższym dobrem; śmierć jest zła, lecz nie jest najwyższym złem ${ }^{15}$. W celu bliższego wyjaśnienia tego stanowiska warto przywołać fragment dzieła Mencjusza: „Życie jest tym, czego chcę; [podobnie] posłuszeństwo stanowi to, czego chcę. Jeśli nie mogę mieć obydwu, wolałbym raczej [wybrać] posłuszeństwo niż życie. Chociaż życie jest tym, czego pragnę, istnieje coś, czego pragnę bardziej aniżeli życia. Właśnie dlatego nie trzymam się życia za wszelką cenę"16. Lepiej jest poświęcić własne życie na rzecz zachowania wartości ren oraz $y i$, będących najwyższym życiowym dobrem człowieka. Warto zasygnalizować, że podobne zapatrywanie na kwestię odebrania życia mieli starożytni stoicy, choć opierali się na nieco odmiennych założeniach.

Jak wiadomo, w wielu sytuacjach mogą ujawniać się konflikty wartości, kiedy nie sposób jednoznacznie odpowiedzieć na pojawiające się dylematy moralne, co dotyczy na przykład problemu eutanazji. Zapewnienie odpowiedniej opieki medycznej jest czymś jak najbardziej pożądanym, jednakże w przypadku niektórych schorzeń (np. nieuleczalne choroby) nawet najlepsza pomoc ze strony lekarza może okazać się nieskuteczna. Wyobraźmy sobie matkę w podeszłym wieku, będącą w stanie terminalnym, która chce przyśpieszyć swoja śmierć po to, aby nie być ciężarem dla swoich najbliższych. Motywacja kobiety wydaje się na pierwszy rzut oka szlachetna (humanitarność), ale może spotkać się z dezaprobatą członków rodziny, zwłaszcza dzieci chcących wypełnić moralny obowiązek troski o rodziców („nabożność synowska”) ${ }^{17}$.

Etyka konfucjańska uderza w zupełnie inną nutę niż etyka liberalna - nie znając idei jednostkowej autonomii i indywidualnej suwerenności, odwołuje się do nadrzędnych celów moralnych każdego człowieka i jego samodoskonalenia. Według uczniów Konfucjusza związki rodzinne są najważniejszą relacją w życiu każdego człowieka i podstawa jego pomyślności. Sprawa życia i śmierci członka wspólnoty rodzinnej nie dotyczy tylko jego samego, lecz powinna stać się przedmiotem troski pozostałych. Pojęcie dobra wspólnego nie jest materialną korzyścią, jaką należy rozdzielić pomiędzy wszystkich po równo z arytmetyczną dokładnością, ale moralnym nakazem realizowanym poprzez konkretne czynności wobec najbliższych osób ${ }^{18}$.

Stanowisko Konfucjusza i jego kontynuatorów wobec problemów bioetycznych wpisuje się, co oczywiste, w kontekst społeczno-kulturowy dawnych i współczesnych Chin. Historia Państwa Środka pokazuje, że konfucjanizm miał zasadnicze znaczenie dla ukształtowania się chińskiego systemu prawnego i moralności publicznej. Jak już wcześniej wspomniano, rządzący powinni pamiętać, że bardziej skutecznym instrumentem służącym do formowania społecznych zachowań jest krzewienie podstawo-

15 P.-Ch. Lo, Confucian Views on Suicide..., s. 69-71.

16 Cyt. za: ibidem, s. 71.

17 J. Chan, Confucian Attitudes toward Ethical Pluralism [w:] The Many and the One: Religious and Secular Perspectives on Ethical Pluralism in the Modern World, eds. R. Madsen, T.B. Strong, PrincetonOxford 2009, s. 146-147.

18 Ibidem. 
wych zasad etycznych niż wprowadzanie regulacji prawnych wspieranych sankcjami. W dziejach cesarskich Chin odnotowano przypadki stosowania na szeroką skale szczególnie surowych środków dla zabezpieczenia porządku państwa, np. okres rzadów cesarza Shi-Huangdi (221-210 r. p.n.e.) czy powstanie tajpingów (1851-1864) ${ }^{19}$.

Konfucjusz przywiązuje raczej większą wagę do edukacji prawnej społeczeństwa niż do „ślepego przymusu” wobec woli władcy: „Gdy ludność poddana / Nie otrzymała wytycznych od pana, / A władca śmiercią nieposłusznych karze, / To jest opresja. Jeżeli w wymiarze / Im dostatecznym nie udzieli rady, / Aby poprawić mogli swoje wady, / A będzie czekał na wynik jedynie, / To okrucieństwo"20. Tym samym kara śmierci dowodzi nie tyle odstraszającej siły państwa, ile w istocie słabej skuteczności norm pozaprawnych we wpływaniu na zachowanie członków danej społeczności.

Jednym z ważniejszych problemów bioetycznych jest kwestia aborcji, czyli zamierzonego przerwania ciąży w wyniku podjęcia czynności i środków zmierzających do zakończenia życia zarodka/płodu. Do dzisiaj nie zachowały się miarodajne informacje z epoki cesarstwa, które bezpośrednio odnosiłyby się do podanego zagadnienia w kontekście idei konfucjanizmu czy neokonfucjanizmu ${ }^{21}$. W perspektywie chińskiej filozofii należy zwrócić uwagę na dwa aspekty - z jednej strony na wartość rodziny i ogólny szacunek dla życia, co wiąże się z postrzeganiem kobiety jako istoty ludzkiej z przyrodzonymi jej prawami, z drugiej zaś na funkcjonowanie kobiety w społeczeństwie i jej szczególną rolę w życiu rodzinnym. Myśl konfucjańska stara się uzyskać względną równowagę między oboma wyżej wymienionymi dobrami, nie zaś dokonać prostego wyboru jednego z nich na rzecz drugiego.

Aby zrozumieć specyfikę chińskiej mentalności, należy zwrócić uwagę na podstawowe znaczenie rodziny i cnót rodzinnych, która to relacja stanowi czynnik stabilizujacy całe życie społeczne. Rodzina jest pojmowana w pewnym sensie jako rozciagająca się w czasie „sztafeta pokoleń”, obejmując przeszłe, obecne i przyszłe generacje. $Z$ jednej strony aborcja jest moralnie naganna, ponieważ pozostaje w sprzeczności z zasadą szacunku do życia i ideału rodziny, w tym potrzebą narodzin i wychowania potomstwa. Z drugiej strony, gdyby ciąża miała powodować dodatkowe trudności dla kobiety, uniemożliwiając jej realizację określonych celów życiowych czy kształtowanie relacji społecznych, może to być przyczynkiem do podjęcia decyzji o aborcji22.

19 Por. China's Death Penalty: History, Law and Contemporary Practices, eds. H. Lu, T.D. Miethe, New York-London 2007, s. 31.

20 Cyt. za: Rozważania (Dialogi konfucjańskie)..., s. 241.

21 N. Jing-Bao, Radical Disagreements of Chinese Views on Fetal Life [w:] The Bioethics of Regenerative Medicine, ed. K.-T. Ip, Dordrecht 2009, s. 69.

22 Por. P.J. Ivanhoe, A Confucian Perspective on Abortion, „Dao”, March 2010, vol. 9, issue 1, s. 41-43. Etyka konfucjańska uznaje aborcję za moralnie złą, co jest uzasadnione nie tyle prawem do życia jednostki jako takiej, ile wynika z szacunku dla indywidulanego życia jako nierozerwalnie złączonego z innymi członkami rodziny żyjącymi wcześniej, obecnie i później. 
Podobne problemy mogą się ponadto pojawić w sytuacji eksperymentów naukowych na ludziach. Zgodnie ze starożytną legendą, opisaną przez Huai Nan Tze, powstanie tradycyjnej medycyny chińskiej łączy się z historią mitycznego cesarza Shennonga - boskiego rolnika, który podjął się sprawdzenia na sobie samym właściwości zdrowotnych różnych gatunków roślin (traw), by pomóc członkom społeczności, do jakiej przybył z wizyta. Główną jego motywacją było doświadczalne poznanie poszczególnych roślin, oddzielenie jadalnych i szkodliwych, co było ważne dla kondycji zdrowotnej całej zbiorowości. Dla Konfucjusza wiedza powinna przynosić określony pożytek, łączyć w sobie znajomość danej dyscypliny naukowej oraz praktyczną mądrość życiową ${ }^{23}$.

We wskazanym ujęciu inicjowanie działań umożliwiających poszerzenie zakresu wiedzy o człowieku jest zgodne ze sprawiedliwością służącą dobru wszystkich ludzi. Wiele myśli chińskiego mistrza daje jasne wskazówki, że jakiekolwiek doświadczenia medyczne należy prowadzić z należytą troską o bliźnich, współczuciem i życzliwością. Czytamy m.in.: „Na miejscu innych kto się stawia osób, / Ten na życzliwość dobry posiadł sposób”; „Zmuszać do czegoś nie pragnę nikogo, / Niech sobie każdy swoją idzie drogą. / I niech mnie też do niczego nie zmusza”; „Jeżeli jest coś, co tobie niemiłe, / Nie zmuszaj innych do tego na siłę"24.

Zapewnienie prawidłowej opieki medycznej nad pacjentem wymaga nie tylko postawienia prawidłowej diagnozy i wyboru odpowiednich środków leczniczych, ale również należytej troski, szlachetności, dobrego słowa. Aby móc w pełni realizować etos lekarza, należy zadbać o ciało i duszę osoby chorej, a więc chodzi tutaj o kompleksowe utrzymanie w należytym stanie obu powyższych elementów. Konfucjanizm stanowił ważną inspirację dla dalszego rozwoju wschodniej medycyny, wywarł przemożny wpływ na ukształtowanie się zasad współczesnej deontologii lekarskiej. To właśnie szesnastowieczny lekarz dynastii Ming, Gong TingXian, kierował się myślą starożytnego mędrca przy opracowaniu słynnych dziesięciu maksym dla lekarzy i dziesięciu maksym dla pacjentów ${ }^{25}$.

Zgodnie z podanymi przezeń zaleceniami lekarze powinni m.in. kierować się w codziennej praktyce zasadą humanitaryzmu, studiować nauki Konfucjusza, rozpoznawać przyczyny chorób, ujawniać prawdę o stanie zdrowia, przywiązywać większą wagę do zasad niż do zysków. Z kolei od pacjentów oczekuje się, aby przyjęli taką postawę, która złagodzi ból i przyspieszy powrót do zdrowia: gotowość do podjęcia leczenia, rozpoczęcie terapii we wczesnej fazie choroby, unikanie emocji i złych myśli, umiarkowanie w jedzeniu i piciu, ponoszenie wydatków na leczenie ${ }^{26}$.

23 Por. X. Chen, A Confucian Reflection on Experimenting with Human Subjects [w:] Confucian Bioethics..., s. 212-213.

24 Cyt. za: Rozważania (Dialogi konfucjańskie)...

25 X. Chen, A Confucian Reflection..., s. 213-214.

26 Tekst dziesięciu maksym dla lekarzy i dziesięciu maksym dla pacjentów, autorstwa Gong Ting Xiana jest dostępny na stronie: http://www.ruhr-uni-bochum.de/healthliteracy/hl-classical-tingxiani-maxime.pdf (dostęp: 5.10.2018). 


\section{Europa - Chiny: bioetyka na styku dwóch różnych tradycji}

Powyższa refleksja na temat kilku wybranych aspektów bioetyki w kontekście filozofii Konfucjusza ukazuje specyfikę chińskiego myślenia o człowieku jako istocie społecznej, zdolnej do osobistego rozwoju jedynie w relacji do innych - rodziny, grupy zawodowej, lokalnej społeczności. Problemy narodzin i śmierci są od wieków przedmiotem refleksji w różnych kulturach/regionach świata, w szczególności na gruncie filozofii, prawa czy religii. Te same pojęcia są odmiennie interpretowane na Wschodzie i Zachodzie, co implikuje określone konsekwencje aksjologiczne. Porównanie dwóch różnych perspektyw rodzi trudności, zwłaszcza ze względu na ukształtowanie nurtu laickiego i religijnego w bioetyce. W dalszych rozważaniach postaram się krótko skonfrontować spojrzenie konfucjańskie oraz zachodnie na podstawowe problemy bioetyczne, podkreślając zarówno elementy wspólne, jak i różnice.

Niepodważalnym dokonaniem europejskiej tradycji intelektualnej, czerpiącej z bogatego dziedzictwa antycznej Grecji i Rzymu oraz myśli chrześcijańskiej, jest uznanie wyjątkowości człowieka jako bytu osobowego, mającego przyrodzona godność oraz zdolność do świadomego i wolnego działania. Współczesne myślenie zachodnie przenika idea ludzkiego indywidualizmu, chociaż już Platon i Arystoteles dostrzegali konieczność powiązania życia człowieka ze społecznością, w jakiej egzystuje (zoon politikon), kształtowania relacji z innymi. Wspólnotowy wymiar ludzkiej egzystencji był zresztą podkreślany także później, tj. w chrześcijaństwie (łac. ecclesia - zgromadzenie) czy przez późniejsze ruchy społeczno-polityczne (hasło liberté, égalité, fraternité). W perspektywach konfucjańskiej oraz arystotelesowskiej zostało uwypuklone znaczenie kolektywnego współżycia ludzi, zwłaszcza wychowanie w rodzinie stanowiącej podstawową komórkę społeczną ${ }^{27}$.

Opisując zjawisko życia, starożytni Grecy posługiwali się dwoma różnymi terminami - bios oraz dzoe. Bios oznacza życie konkretnej istoty ludzkiej, podlegające śmierci, w przeciwieństwie do dzoe przenikającego całą naturę, niezniszczalnego i pozbawionego indywidualnych właściwości ${ }^{28}$. Chińska filozofia bazuje na koncepcji tao (道), wyrażającej powszechnie panujący w świecie przyrodniczym i społecznym ład. Życie człowieka jest wpisane w ogólny cykl przemian życia i śmierci zachodzący w świecie natury - ,natura jest żywiołem cyklicznym, dokładnie tak jak Tao, koniec staje się początkiem, początek powraca na koniec"29. Wszelka

${ }^{27}$ Jak pisze J. Yu: „Przypisanie rodzinie ważnego miejsca w filozofii moralności jest tym punktem myśli Konfucjusza i Arystotelesa, który odróżnia ją od nowoczesnej etyki”; cyt. za: J. Yu, The Ethics of Confucius and Aristotle: Mirrors of Virtue, New York-London 2013, s. 121.

28 I. Trzcińska, Logos, mit i ratio: wybrane koncepcje racjonalności od XV do XVII wieku, Kraków 2011, s. 155.

29 Cyt. za: Tao Te Ching, tłum. W.P.P. Zieliński, Poznań 2009, s. 90. 
ingerencja $\mathrm{w}$ istniejący rytm zdarzeń i zjawisk jest niezgodna $\mathrm{z}$ naturalnym porządkiem rzeczy (無為 - wu-wer). Dzięki taoizmowi konfucjańska wizja życia została wzbogacona o elementy indywidualizmu, perfekcjonizmu czy podporządkowania naturze rzeczy ${ }^{30}$.

Narodziny oraz śmierć człowieka jako dwa punkty graniczne jego egzystencji były ważnym elementem rozważań etycznych nie tylko w Chinach, ale również w zachodnim kręgu kulturowym. Przerywanie ciąży praktykowano w antycznej Grecji i Rzymie, ze względów eugenicznych było aprobowane przez Platona i Arystotelesa, mimo traktowania nienarodzonych jako istot duchowo-cielesnych. Interesujące jest, że stanowisko to było uzasadnione nie tyle dobrem ciężarnej kobiety, ile ochroną kondycji biologicznej ogółu społeczeństwa. Wraz z powstaniem chrześcijaństwa i uformowaniem koncepcji osoby aborcja została oceniona jako moralnie niedopuszczalna, porównywalna z zabójstwem. Z kolei eutanazja traktowana jako „dobra śmierć” spotkała się z negatywną oceną Hipokratesa i Pitagorasa, w przeciwieństwie do wyżej wspomnianych Platona i jego ucznia. Jednak samobójstwo jako takie nie zyskało uznania w ich oczach, aczkolwiek miało zwolenników wśród cyników, cyrenaików, stoików. Ponadto na uwagę zasługuje twierdzenie Arystotelesa w sprawie wykonywania kary śmierci, która jego zdaniem powinna pełnić funkcje lekarstwa dla samego przestępcy za popełnione zło, nie zaś stanowić narzędzie zemsty społeczeństwa ${ }^{31}$.

Współczesne odkrycia naukowe na polu biomedycyny uświadomiły nam, że rozwój technologiczny powinien być paralelny z praktyką etyczna, dzięki czemu można harmonijnie pogodzić obie sfery życia ludzkiego. Okazuje się, że wiele zagadnień poruszanych w dawnych tradycjach filozoficznych pozostaje jak najbardziej aktualnych również w dzisiejszych warunkach społecznych. Myśl Konfucjusza żyjącego na przełomie VI/V wieku p.n.e., następnie rozwijana przez jego kontynuatorów (Mencjusza, Xunzi), była istotnym czynnikiem kulturotwórczym w Chinach, oddziałując na kształt ideologii państwowej, instytucje prawne, zasady etyczne. Konfucjanizm stanowi nieodłączny element mentalności współczesnych mieszkańców wielu krajów Dalekiego Wschodu, mając podobne znaczenie kulturowe jak chrześcijaństwo na Zachodzie ${ }^{32}$. Pojęcie „bioetyka konfucjańska” należy ogólnie rozumieć jako refleksję na temat życia w kontekście postępu naukowo-badawczego, przy wykorzystaniu dorobku myśli Konfucjusza i jego następców. Wydaje się, że to dziedzictwo intelektualne Dalekiego Wschodu może twórczo oddziaływać nie tylko na kierunek rozważań teoretycznych, ale również na aktualną praktykę biomedyczna. Paradygmat zachodniej bioetyki ma tendencję do uniwersalizacji, przez co ogra-

\footnotetext{
30 R. Tokarczyk, Prawa narodzin, ṡycia i śmierci, Warszawa 2012, s. 55.

31 Por. M. Czachorowski, hasła: Aborcja; Eutanazja; Kara śmierci [w:] Powszechna encyklopedia filozofii, t. 1, red. A. Maryniarczyk, Lublin 2000, s. 22-26, 321-325, 483-486.

32 Por. R. Tokarczyk, Wspótczesne kultury prawne, Warszawa 2010, s. 247-248.
} 
nicza wpływy „bioetyk regionalnych”, które wyrażają swoisty dla danego obszaru geograficznego sposób postrzegania rzeczywistości.

U podstaw nowożytnej zachodniej koncepcji społeczeństwa leży przeświadczenie, że powstaje ono w drodze dobrowolnej umowy racjonalnych i wolnych jednostek w celu osiagania wspólnych korzyści. Zawarcie umowy społecznej jest motywowane rachunkiem indywidualnych praw i wolności, dlatego też u jego podstaw leży korzyść (por. konfucjańskie li), nie zaś wymóg powinności z uwagi na dobro moralne (por. konfucjańskie yi). Przedmiotowe pojęcie tworzy poważne implikacje dla właściwego rozumienia istoty ludzkiej w jej wymiarach biologicznym i społecznym, podkreślając konwencjonalny status człowieka czy relacji międzyludzkich. Wyrastający z liberalnej tradycji Zachodu kontraktualizm traktował istoty ludzkie jako podmioty autonomiczne, wzajemnie konkurujące z soba, zdolne jednak do zachowań altruistycznych, które dążą do wzmocnienia własnych interesów w obrębie powołanej przez siebie organizacji politycznej. Kontestacji uległa wartość naturalnych, przyrodzonych, właściwych człowiekowi specyficznych więzi życiowych, takich jak rodzina, społeczność lokalna, grupa etniczna ${ }^{33}$.

Azjatycki styl myślenia o człowieku i świecie przyrodniczym pozostaje uwarunkowany funkcjonowaniem trzech tradycji filozoficzno-religijnych, tj. konfucjanizmu, taoizmu oraz buddyzmu, tworzących etos dalekowschodni. Podane tradycje łączy holistyczne ujęcie rzeczywistości, przywiązują dużą wagę do wartości kolektywnych, jak przyroda, społeczeństwo, sąsiedztwo, konieczność harmonijnego współdziałania na rzecz dobra wspólnoty. Rozwój naukowo-technologiczny ujawnia liczne problemy bioetyczne odnoszące się do wszelkiego życia organicznego - człowieka, zwierząt, roślin, dlatego też podejmuje się próbę reinterpretacji idei praw człowieka na rzecz rozszerzenia katalogu praw na inne istoty żywe ${ }^{34}$.

Poszukiwanie właściwych rozwiązań dla bioetyki wymaga przyjęcia wyjściowej tezy, iż cała rzeczywistość przyrodnicza stanowi jednorodny, ale złożony byt, przejawiający się w występowaniu różnych form życiowych powiązanych wzajemnymi relacjami. Optyka konfucjańska jest szczególnie cenna dla kultury Zachodu zdominowanej przez mechanicystyczne pojmowanie świata, rzucając nowe światło na

33 Por. P. Skrzydlewski, Umowa społeczna [w:] Powszechna encyklopedia..., s. 1-5; http://www.ptta. pl/pef/pdf/suplement/umowa_s.pdf (dostęp: 16.10.2018).

${ }_{34}$ H. Sakamoto, The Foundations of a Possible Asian Bioethics [w:] Bioethics: Asian Perspectives: A Quest for Moral Diversity, ed. R.-Z. Qiu, Dordrecht 2004, s. 47-48. Stanowisko to stopniowo zyskuje uznanie naukowców, np. podczas konferencji w Helsinkach w 2010 r. przyjęto Deklarację praw waleni: wielorybów i delfinów, potwierdzając szczególny status tych organizmów, które powinno się postrzegać jak osoby, z poszanowaniem ich praw do życia i wolności. W 2013 r. rząd Indii wydał oficjalne oświadczenie, że delfiny „powinny być traktowane jako »osoby inne niż ludzie« i jako takie posiadać swoje własne szczególne prawa”, https://www.cetaceanrights.org/; https://www.dw.com/en/dolphins-gain-unprecedented-protection-in-india/a-16834519 (dostęp: 10.10.2018). 
kwestie aksjologiczne, antropologiczne czy biojurysprudencję. Przywołane postulaty z zakresu bioetyki znajdują swój oddźwięk wśród niektórych zachodnich autorów. Zdaniem amerykańskiego filozofa Paula Taylora wszyscy ludzie są elementem wspólnoty życia na tych samych zasadach jak inne organizmy żywe, zaś gatunek homo sapiens, wraz z innymi gatunkami, jest nieodłączną częścią systemu wzajemnych powiązań. Autor ten podkreśla przy tym, że wszystkie istoty żywe stanowią „teleologiczne centra życia”, a każda z nich cechuje niepowtarzalność i ukierunkowanie na osiaganie własnego dobra ${ }^{35}$.

Twierdzenia niektórych uczonych, które postuluja przeorientowanie chińskiego modelu na zachodni, indywidualistyczny, mający rzekomo lepiej odpowiadać autonomii pacjentów, są nietrafne, ponieważ nie uwzględniają warunków lokalnych oraz tradycji społeczno-kulturowych ${ }^{36}$. Zasady konfucjańskie nie straciły na aktualności, wywierając wpływ na współczesna praktykę medyczną w Chinach. Konfucjanizm łączy wszelkie ludzkie działanie z powinnością prowadzenia dobrego życia, zawierając zalecenia moralne, np. do jakich celów należy dążyć, jak podejmować słuszne decyzje czy w jaki sposób leczyć innych ludzi. Właściwy model opieki zdrowotnej powinien zostać oparty przede wszystkim na trosce rodziny i lokalnej społeczności o chorych, zaś w mniejszym zakresie na rządowej polityce zdrowotnej ${ }^{37}$.

Rodzina zajmuje istotne miejsce w chińskiej kulturze medycznej, również w samym procesie decyzyjnym dotyczącym pacjenta - to ona ma prawo podjąć ostateczną decyzję, czy powiedzieć prawdę o stanie zdrowia choremu członkowi rodziny ${ }^{38}$. W tradycji Chin głęboko zakorzeniła się konfucjańska cnota nabożności synowskiej, która wymaga od dorosłych dzieci zapewnienia opieki nad starszymi rodzicami, powszechnie praktykowana również w dzisiejszych czasach ${ }^{39}$. Jak słusznie zauważył Ruiping Fan: „uznanie prawdy konfucjańskiego rozumienia moralności i bioetyki

35 P.W. Taylor, Respect for Nature. A Theory of Environmental Ethics, Princeton 1986, s. 99-100, za: G. Hołub, Ocena moralna GMO. Postulaty etyki środowiskowej [w:] Genetycznie modyfikowany organizm jako przedmiot oceny moralnej, red. A. Bobko, A. Cynk, Rzeszów 2014, s. 69.

36 X. Chen, R. Fan, The Family and Harmonious Medical Decision Making: Cherishing an Appropriate Confucian Moral Balance, ,Journal of Medicine and Philosophy” 2010, vol. 35, s. 574.

37 Por. R. Fan, Just Health Care, The Good Life, And Confucianism [w:] Confucian Bioethics..., s. 274-278; D. Rui, A Family-Oriented Decision-Making Model for Human Research in Mainland China, „Journal of Medicine and Philosophy” 2015, vol. 40, s. 400-417.

38 Wartość relacji z bliskimi zyskała swój normatywny wyraz w wytycznych biomedycznych z 2008 r. dotyczących świadomej zgody pacjenta, np. „Każda informacja, która może zwiększyć psychiczne obciażenie pacjenta, powinna najpierw zostać zaproponowana rodzinie lub prawowitemu opiekunowi; powinna być zaproponowana pacjentowi tylko wtedy, gdy pozwala na to stan pacjenta”; „W każdym przypadku, gdy nie jest właściwe, by pacjent został poinformowany o swoim stanie zdrowia, rodzina pacjenta lub prawowity opiekun powinien mieć możliwość wyrazić ustną lub pisemna zgodę na propozycję leczenia dla pacjenta”, za: X. Chen, R. Fan, The Family and Harmonious...

39 D.A. Bell, China's New Confucianism, New Jersey 2008, s. 25. 
nie jest oparte jedynie na oczekiwanej analizie kosztów i korzyści. Aby to osiagnać, potrzeba raczej doświadczenia ugruntowanego w postawie szacunku, która otwiera serce lub, jak mówili Grecy, nous, na rzeczywistość konfucjańskiego familizmu”º.

\section{Podsumowanie}

Począwszy od opublikowania w 1979 r. pracy Toma L. Beauchampa i Jamesa F. Childressa Principles of Biomedical Ethics, poszczególni autorzy zachodni proponują ustalić pewne katalogi zasad, jakie powinny znajdować odzwierciedlenie w etyce medycznej ${ }^{41}$. Na płaszczyźnie bioetyki zwrócono uwagę na występowanie istotnych podobieństw pomiędzy etyką konfucjańską a zasadą poszanowania autonomii. Według Konfucjusza moralna doskonałość wymaga umiejętności zachowywania w życiu cnót wierności (xin), prawości (gong) i szacunku (jing), które odpowiadaja przywołanej zachodniej zasadzie autonomii oraz powiązanym z nią zasadom szczerości (veracity) i wierności (fidelity).

Nauki starożytnego myśliciela odwołują się do wzoru osobowego junæi, oznaczającego człowieka, który wypełnia w swoim życiu konfucjańskie cnoty, dąży do samodoskonalenia, samodzielności, wewnętrznej moralnej autonomii. Obraz ten ilustruje podmiot predysponowany do niezależnego działania, wyrażający godność i wartość istoty ludzkiej, przejawiającej szacunek wobec innych ludzi ${ }^{42}$. Interesujące jest to, że bioetyka czterech cnót, sformułowana w XX wieku przez Beauchampa i Childressa, wyraźnie koresponduje ze starożytną etyką Konfucjusza ${ }^{43}$. Charakterystycznym rysem chińskiej filozofii jest położenie nacisku na wymiar wspólnotowy (rodzinny, lokalny, państwowy), powinność sumiennego wypełniania swoich obowiazków w zależności od miejsca w hierarchii społecznej, jak również wymóg przestrzegania obowiązującej etykiety.

Tradycyjnemu chińskiemu myśleniu towarzyszy idea, że społeczeństwo funkcjonuje jak żywy organizm, tworząc harmonijna, uporządkowaną całość. Jakość ludzkiego życia zależy nie tylko od indywidualnego samodoskonalenia, lecz także od kształtowania relacji rodzinnych, grupowych, społecznych. Idee konfucjańskie stanowią dorobek kulturowy Państwa Środka, który z powodzeniem może inspirować do pozytywnych zmian zachodnią bioetykę. Wypełnianie społecznych powinności

40 Cyt. za: R. Fan, Confucian Familism and Its Bioethical Implications [w:] The Family, Medical Decision-Making, and Biotechnology: Critical Reflections on Asian Moral Perspectives, ed. S.Ch. Lee, Dordrecht 2007, s. 20.

41 T.L. Beauchamp i J.F. Childress są znani jako twórcy pryncypializmu, który jest ufundowany na czterech następujących zasadach: autonomii, dobroczynności, nieszkodzenia i sprawiedliwości.

42 Por. D.F.-C. Tsai, The Bioethical Principles and Confucius' Moral Philosophy, „Journal of Medical Ethics", March 2005, vol. 31, issue 3, s. 159-160.

43 Ibidem, s. 162. 
w duchu altruizmu, humanitaryzmu, wrażliwości nie jest obce zachodniej filozofii medycznej, jednakże współcześnie osłabianej przez wartości indywidualizmu, utylitaryzmu, samorealizacji.

Bioetyka konfucjańska podkreśla właśnie znaczenie etycznego wymiaru relacji lekarz - pacjent, w której należy patrzeć na drugiego nie jako na odosobnioną „monadę", ale jako na istotę relacyjną, zdolną do prawidłowego rozwoju w specyficznych związkach z innymi. Szacunek wobec dzielących różnic, kultury czy pochodzenia będzie decydował o wartości tego spotkania, uświadamiając konieczność podejmowania wszelkich czynności medycznych w duchu zasady humanitarności (ren - dosł. „stawanie się osobą), mając na celu dobro człowieka.

\section{SUMMARY}

\section{CONFUCIAN BIOETHICS AS A RESPONSE TO THE CHALLENGES OF MODERN MEDICINE}

The dynamic development of biology, medicine and technology is one of the main reasons behind ethical reflection on interference in the natural processes of life, which has led to the emergence of a new interdisciplinary field - bioethics. This approach combines scientific knowledge and ethical values, and indicates the need to reconcile the achievements of science and humanistic values, as determinants for mutual relations between science and ethics. The originality of Chinese culture inspires us to appreciate Confucian philosophy, which is a cultural repository of knowledge about human life, personal relations and connections between human beings and nature. In this text, I describe some basic problems of bioethics, e.g. euthanasia, suicide, abortion, and the death penalty, from the perspective of Confucian and Western bioethics. Confucius's ethical thought is based on five regulations: humaneness $(r e n)$, righteousness $(y i)$, ritual $(l i)$, wisdom (zhi), and faithfulness (xin), which determine the boundaries of human activity. These ideas underlie the cultural richness of modern Chinese bioethics and they can successfully inspire European bioethics; therefore they promote mutual understanding between East and West. 